\title{
Monitoring the Air Quality in Conventional Wet Machining
}

Julia Hricova, Erika Sujova, Petra Semanova

Faculty of Environmental and Manufacturing Technology, Technical university in Zvolen, Studentska 26, 96053 Zvolen, Slovak Republic, E-mail: julia.hricova@tuzvo.sk, erika.sujova@tuzvo.sk

Metalworking fluid (MWF) aerosols are generated continuously during conventional machining operations and can have a number of adverse health effects. Exposure to the aerosols has often been reported to cause acute respiratory difficulties including asthma, hypersensitive pneumonitis and lung cancer. Aerosol measurement data was conducted to identify the major determinants that may affect exposure to aerosol fractions during turning of a cylindrical work piece on an uncovered conventional lathe. The aerosol mass concentration was investigated as function of spindle speed, fluid flow rate and sampling position. Synthetic fluid, mixed at $5 \%$ concentration with water, was applied via nozzle centred above the work piece at a distance of $70 \mathrm{~mm}$. The aerosol mass concentration was determined gravimetrically and particle size analysis was performed by optical method. The results show that aerosol mass concentration increases with increasing the fluid flow rate and decreases by increasing the spindle speed. Moreover, the particle size analysis detected that a high quantity of particles smaller than $0.2 \mathrm{~mm}$ is generated at higher spindle speeds.

Keywords: Metalworking Fluid, Aerosol, Mass Concentration, Particle Size, Turning

\section{Acknowledgements}

The authors gratefully acknowledge to SGA SR for funding assistance of research project VEGA 1/0114/11 and project IPA 4/2014 "Research the process of dispersion aerosol during metalworking".

\section{References}

[1] HWANG, J., CHUNG, E. S. (2003). Analysis of cutting fluid atomization and environmental impact through spinoff mechanism in turning operation for environmentally conscious machining (I). In: International journal of the Korean society of precision engineering, Vol. 4, No. 1, pp. 49-55.

[2] YUE, Y., OLSON, W. W., SUTHERLAND, J. W. (1996). Cutting fluid mist formation via atomization mechanisms. In: Proceedings of symposium on design for manufacturing and assembly. ASME Bound Volume-DE, Vol. 89, pp. 37-46.

[3] KO, T. J., PARK, S. H., KIM, H. S. (2003). Experimental verification of the mist generation mechanism in turning. In: International journal of machine tools \& manufacture, Vol. 43. pp. 115-120.

[4] SÝKOROVÁ, L., LUKOVICS, I. (2008). The effect or grinding fluid nozzle geometry on jet coherent cutting. In: Manufacturing Technology, Vol. 8, pp. 31-35.

[5] MÁDL, J. (2002). Dry machining versus cutting with cutting fluids. In: Manufacturing Technology, Vol. 3, pp. $42-45$

[6] MÁDL, J., KOUTNÝ, V. (2002). How to select suitable cutting fluid. In: Manufacturing Technology, Vol. 3, pp. 45-53.

[7] JERSÁK, J., REJZEK, M. (2011). Účinek procesní kapaliny na proces soustružení a vybrané parametre integrity povrchu. In: Strojírenská technologie, Vol. 3, pp. 17-23.

[8] HOLEŠOVSKÝ, F., HRALA, M. (2009). Process liquid reduction in grinding. In: International Journal of Computational Materials Science and Surface Engineering, Vol. 3, No.1, pp. 43-51.

[9] DADO, M., HNILICA, R. (2009). Control measures for minimizing exposure to metalworking fluid aerosols. In: Josra [online] = Journal of safety research and applications, Vol. 3. ISSN 1803-3687.

[10] DADO, M., HNILICA, R. (2009). Review of methods for measuring occupational exposure to metal-working fluid mist. In: Proceedings of the 4th international scientific conference Safety-Quality-Reliability, pp. 47 - 51, TU Košice. ISBN 978-80-553-0137-2.

[11] ČIERNA, H., ŤAVODOVÁ, M. (2013). Using the design of experiment method to evaluate quality of cuts after cutting aluminum alloy by AWJ. In: Manufacturing technology, Vol. 13, No. 3, pp. 303-307.

[12] NAŠČÁK, L., KOLEDA, P. (2011). Creating of 3D picture in Matlab. In: Annals of DAAAM for 2011 \& proceedings of the 22nd international DAAAM symposium "Intelligent manufacturing \& automation: power of knowledge and creativity": 23-26th November 2011, Vienna, Austria. Vol. 22, no. 1, pp. 1159-1160. ISBN 978-3-90150983-4. ISSN 1726-9679.

[13] KOLEDA, P. (2012). Metóda optoelektronického merania malých častíc pri trieskovom obrábaní dreva. Dizertačná práca. TU, Zvolen, 110s. 
[14] CHEN, Z., ATMADI, A., STEPHENSON, D. A., LIANG, S. Y., \& VENUVINOD, P. K. (2000). Analysis of Cutting Fluid Aerosol Generation for Environmentally Responsible Machining. CIRP Annals - Manufacturing Technology, Volume 49, No. 1, pp. 53-56.

[15] CHEN, M., TSAI, P.J., CHANG, CH.CH., SHIH, T.-SH., LEE, W.J., \& LIAO, P.C. (2007). Particle size distributions of oil mists in workplace atmospheres and their exposure concentrations to workers in a fastener manufacturing industry, Journal of Hazardous Materials, Volume 146, pp. 393-398.

[16] DASCH, J. M., ANG, C. C., MOOD, M., \& KNOWLES, D. (2002). Variables affecting mist generation from metal removal fluids. Lubrication Engineering, Volume 58, No. 3, pp. 10-17.

[17] THORNBURG, J., LEITH, D. (2000). Mist generation during metal machining. Journal of Tribology, Volume 122, No. 3, pp. 544-549.

[18] THORNBURG, J., LEITH, D. (2000). Size distribution of mist generated during metal machining. Applied Occupational and Environmental Hygiene, Volume 15, No. 8, pp. $618-628$.

[19] SOKOLOVIĆ, D., HÖFLINGER, W., ŠEČEROV SOKOLOVIĆ, R., SOKOLOVIĆ S., \& SAKULSKI D. (2013). Experimental study of mist generated from metalworking fluids emulsions, Journal of Aerosol Science, Volume 61, pp. 70-80.

[20] GRESSEL, M. G. (2001). Comparison of mist generation of flood and mist application of metalworking fluids during metal cutting. Doctoral dissertation.

[21] GUNTER, K. L., SUTHERLAND, J. W. (1999). An experimental investigation into the effect process conditions on the mass concentration of cutting fluid mist in turning. In: Journal of Cleaner Production, Vol. 7. pp. 341-330.

[22] HEITBRINK, W. A., D'ARCY J. B., YACHERT J. M. (2000). Mist Generation at a Machining Center. In: AIHAJ - American Industrial Hygiene Association, Vol. 61, No. 1, pp. 22-30.

Copyright $($ C 2014. Published by Manufacturing Technology. All rights reserved. 